\title{
Meridional transport and deposition of atmospheric ${ }^{10} \mathrm{Be}$
}

\author{
U. Heikkilä ${ }^{1}$, J. Beer ${ }^{1}$, and J. Feichter ${ }^{2}$ \\ ${ }^{1}$ EAWAG, Überlandstrasse 133, 8600 Dübendorf, Switzerland \\ ${ }^{2}$ Max-Planck Institute for Meteorology, Hamburg, Germany
}

Received: 4 July 2008 - Published in Atmos. Chem. Phys. Discuss.: 8 September 2008

Revised: 15 December 2008 - Accepted: 15 December 2008 - Published: 23 January 2009

\begin{abstract}
Be}$ concentrations measured in ice cores exhibit larger temporal variability than expected based on theoretical production calculations. To investigate whether this is due to atmospheric transport a general circulation model study is performed with the ${ }^{10} \mathrm{Be}$ production divided into stratospheric, tropospheric tropical, tropospheric subtropical and tropospheric polar sources. A control run with present day ${ }^{10} \mathrm{Be}$ production rate is compared with a run during a geomagnetic minimum. The present ${ }^{10} \mathrm{Be}$ production rate is $4-5$ times higher at high latitudes than in the tropics whereas during a period of no geomagnetic dipole field it is constant at all latitudes. The ${ }^{10} \mathrm{Be}$ deposition fluxes, however, show a very similar latitudinal distribution in both the present day and the geomagnetic minimum run indicating that ${ }^{10} \mathrm{Be}$ is well mixed in the atmosphere before its deposition. This is also confirmed by the fact that the contribution of ${ }^{10} \mathrm{Be}$ produced in the stratosphere is dominant (55\%-70\%) and relatively constant at all latitudes. The contribution of stratospheric ${ }^{10} \mathrm{Be}$ is approximately $70 \%$ in Greenland and $60 \%$ in Antarctica reflecting the weaker stratosphere-troposphere air exchange in the Southern Hemisphere.
\end{abstract}

\section{Introduction}

Cosmogenic radionuclides, such as ${ }^{10} \mathrm{Be}$, are excellent tools to study past solar activity and past geomagnetic field strength (Beer et al., 1988). They are produced in the atmosphere by nuclear interactions between the high-energetic galactic cosmic ray particles and atmospheric atoms. Because of the modulation of the cosmic ray intensity by the solar wind as well as the geomagnetic field strength the produc-

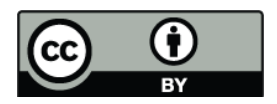

Correspondence to: U. Heikkilä (ulla.heikkilae@eawag.ch) tion of cosmogenic radionuclides has a strong latitude and altitude (atmospheric pressure) dependence (Lal and Peters, 1967; Masarik and Beer, 1999). Recently there have been several studies of the past solar activity (McCracken et al., 2004a; Muscheler et al., 2007; Vonmoos et al., 2006) based on ${ }^{10} \mathrm{Be}$ records from polar ice cores. However, the interpretation of the ${ }^{10} \mathrm{Be}$ data is hampered by the uncertainty introduced by the transport of the ${ }^{10} \mathrm{Be}$ atoms from their origin to the archives and the wet and dry scavenging processes which are responsible for the removal of the ${ }^{10} \mathrm{Be}$ atoms from the atmosphere.

The relationship between the measured ${ }^{10} \mathrm{Be}$ fluxes and concentrations in ice cores and the global production rate is not yet fully understood. One open question concerns the source region of ${ }^{10} \mathrm{Be}$ which is deposited in polar areas. Because of the geomagnetic shielding the solar modulation of ${ }^{10} \mathrm{Be}$ is strongest at high latitudes (Lal and Peters, 1967; Masarik and Beer, 1999). If the ${ }^{10} \mathrm{Be}$ deposited in polar ice originated only from latitudes pole-wards of $60^{\circ}$ interpreting the variability of the measured ${ }^{10} \mathrm{Be}$ concentrations in ice as global production variability would lead to an overestimation of the global production variability. However, there are several reasons to assume that significant mixing takes place in the atmosphere before the ${ }^{10} \mathrm{Be}$ atoms are deposited. The major part of ${ }^{10} \mathrm{Be}$ is produced in the stratosphere $(50-75 \%$ depending on solar activity (Heikkilä et al., 2008a; Masarik and Beer, 1999) and the tropopause height), where ${ }^{10} \mathrm{Be}$ is mixed within the average residence time of 1-2 years to such an extent that the ${ }^{10} \mathrm{Be}$ mixing ratio in the air coming from the stratosphere can be assumed to represent the mean stratospheric production within each hemisphere. Therefore we call the ${ }^{10} \mathrm{Be}$ in the stratosphere "well mixed" although the stratosphere is stably layered and cannot be understood as a mixer. The mixing within each hemisphere is sufficient to mask the latitudinal dependence of the production of ${ }^{10} \mathrm{Be}$ because it can be considered symmetric in both hemispheres.

Published by Copernicus Publications on behalf of the European Geosciences Union. 
The exchange between stratosphere and troposphere mainly takes place at the subtropical tropopause breaks (Stohl et al., 2003), meaning that ${ }^{10} \mathrm{Be}$ produced in the stratosphere is mainly deposited in the subtropics. The amount of ${ }^{10} \mathrm{Be}$ produced in the troposphere at high latitudes is relatively small because the tropopause lies at a higher pressure at high latitudes than in the tropics. Therefore, so far a rather well mixed atmosphere has been assumed for solar activity reconstructions based on ${ }^{10} \mathrm{Be}$ from polar regions (McCracken et al., 2004a; Muscheler et al., 2007; Vonmoos et al., 2006). However, other studies have questioned this assumption and introduced a so-called polar enhancement coefficient (PEC) which corrects for the higher modulation of the production rate at high latitudes.

Mazaud et al. (1994) were the first to estimate the origin of ${ }^{10} \mathrm{Be}$ measured in the Vostok ice core. By identifying which part of the ${ }^{10} \mathrm{Be}$ was modulated by the geomagnetic field strength they concluded that $25 \%$ of ${ }^{10} \mathrm{Be}$ was locally produced and $75 \%$ originated from lower latitudes. Steig et al. (1996), instead, found that only $35 \%$ of ${ }^{10} \mathrm{Be}$ at Taylor Dome, Antarctica, can be derived from low-latitude sources. On the other hand, they also found a strong correlation between the Taylor Dome data and ${ }^{10} \mathrm{Be}$ production rates from the whole atmosphere or the whole stratosphere as predicted from the neutron monitor data. Bard et al. (1997) make the assumption that the ${ }^{10} \mathrm{Be}$ in polar regions is produced pole-wards of $60^{\circ}$, both in the stratosphere and the troposphere and falls down locally. Using this assumption they calculated a theoretical correction value for the polar enhancement, which was 0.65 when assuming a variability of the ${ }^{10} \mathrm{Be}$ production of $17 \%$ between solar minimum and maximum. McCracken (2004b) introduced 5 different mixing models of the source regions of ${ }^{10} \mathrm{Be}$ and tested the influence of varying fraction of ${ }^{10} \mathrm{Be}$ from the lower latitudes. However, the different character of the circulation in the stratosphere and the troposphere was not taken into account.

Recently Field et al. (2006) studied the effect of polar enhancement using a general circulation model (GCM). They found an enhancement of $20 \%$ of the ${ }^{10} \mathrm{Be}$ deposition fluxes near the poles during a solar minimum (drop from $\Phi=700 \mathrm{MeV}$ to $500 \mathrm{MeV}$ ), and a suppression of $20 \%$ during a geomagnetic minimum (reduction of $25 \%$ of the field strength). In comparison, another recent model study by Heikkilä et al. (2008a), which investigated an even larger solar minimum (the Maunder Minimum, $\Phi=200 \mathrm{MeV}$ ), combined with a climate cooling, found no indication of a polar enhancement. Both model studies agree, however, that the climatic conditions, such as changes in the tropospheric transport or precipitation rate, add some uncertainty to the global production signal in the polar ${ }^{10} \mathrm{Be}$ deposition fluxes. It is quite difficult to quantify this uncertainty. Heikkilä et al. (2008a) found a meteorological "noise" in the zonal mean deposition fluxes of mostly less than $25 \%$ of the total production change between present day and the Maunder Minimum, which can be considered as an extreme climate change for the
Holocene. However, this amount depends on the magnitude and type of climate change, as was shown by the different experiments made by Field et al. (2006).

The aim of this study is to improve the interpretation of ${ }^{10} \mathrm{Be}$ from the ice cores by tracing back the origin of the ${ }^{10} \mathrm{Be}$ atoms which are deposited in polar regions. The main goals are: 1) to quantify the contribution of different latitudes to the measured ${ }^{10} \mathrm{Be}$ flux at a given site, 2) to investigate the postulated polar enhancement in the ${ }^{10} \mathrm{Be}$ deposition and 3 ) to determine whether the fraction of stratospheric to locally produced atmospheric ${ }^{10} \mathrm{Be}$ in ice cores depends on the production rate. Therefore we carried out two experiments with extremely different ${ }^{10} \mathrm{Be}$ production distributions in the atmosphere.

The first experiment was performed with zero geomagnetic field strength. This leads to a ${ }^{10} \mathrm{Be}$ production rate which is constant at all latitudes, leading to no change polewards of $60^{\circ}$ but to an extreme change of up to a factor of 4-5 at low latitudes. This experiment is called "Laschamp". During the so-called Laschamp event, a geomagnetic excursion which took place approximately $40 \mathrm{kyr}$ before present, the strength of geomagnetic field was close to zero, leading to an enhanced production of ${ }^{10} \mathrm{Be}$. This peak can be observed in all ice cores (GRIP, Vostok, Dome C, Byrd and Camp C) covering this period (Baumgartner et al., 1998; Yiou et al., 1985; Raisbeck et al., 1987; Beer et al., 1984, 1987). We use the name "Laschamp" for this experiment for the simplicity throughout the manuscript although this study is conceptual and considers only the ${ }^{10} \mathrm{Be}$ production change. The ice age climatic conditions during the real Laschamp event were not taken into account. Therefore it is also not possible to compare the results of this study with the measured ${ }^{10} \mathrm{Be}$ ice core concentrations.

The Laschamp experiment was compared with a second experiment representing the present day conditions (this run is referred to as the control run throughout the manuscript). The climatic conditions were the same in both experiments, as well as the solar activity $(\Phi=700 \mathrm{MeV})$. In order to investigate at which latitudes the ${ }^{10} \mathrm{Be}$ in ice cores was produced, the ${ }^{10} \mathrm{Be}$ source was divided into seven different components, roughly following the atmospheric circulation structure. The

${ }^{10} \mathrm{Be}$ produced in the whole stratosphere was considered as one component while the tropospheric ${ }^{10} \mathrm{Be}$ was divided into 30-degree latitude bands: ${ }^{10} \mathrm{Be}$ produced in the tropics, subtropics and polar areas, both for the Northern and the Southern Hemisphere. Another interesting issue to investigate is whether there are differences in the stratospheric and local fractions of ${ }^{10} \mathrm{Be}$ between the hemispheres.

\section{Model description and setup}

The model employed for this study was the ECHAM5-HAM general circulation model. ECHAM5 is the fifth-generation atmospheric global circulation model (GCM) developed at 


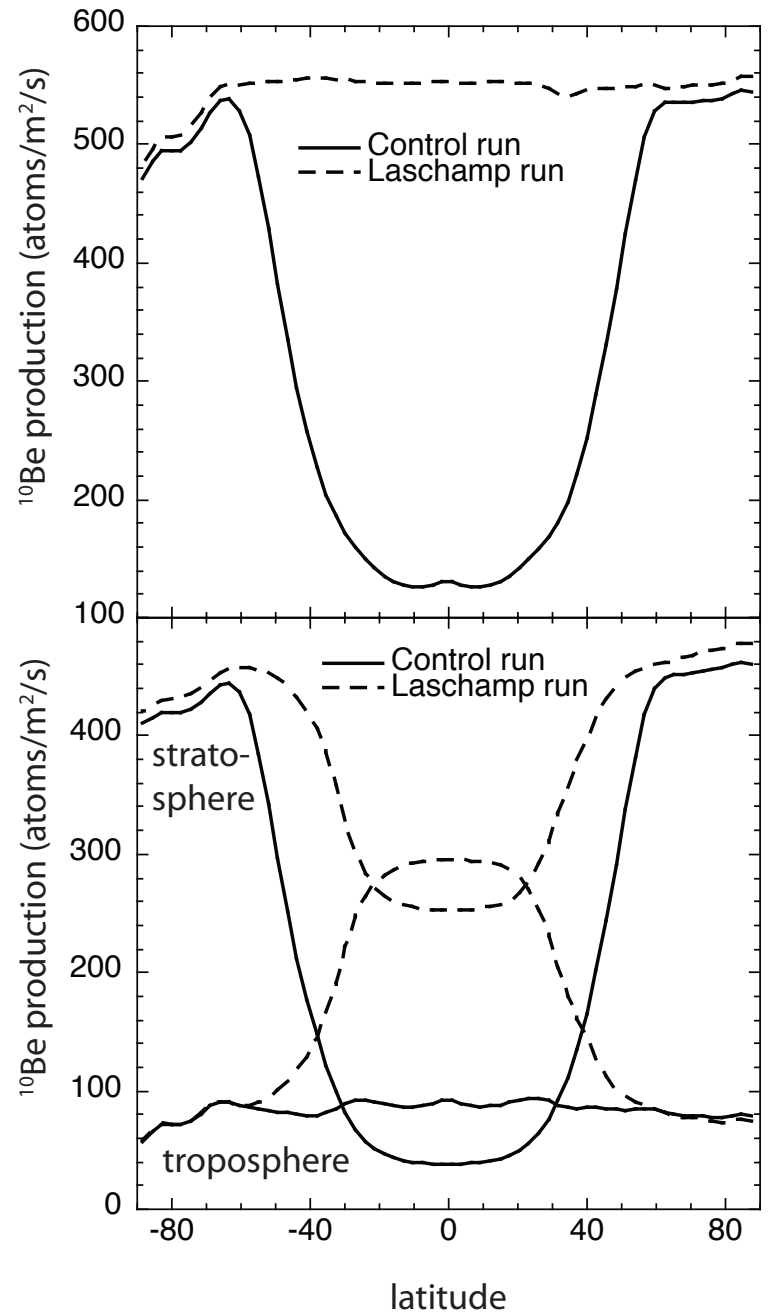

Fig. 1. Zonal mean ${ }^{10} \mathrm{Be}$ total production fluxes (top) in the control run (solid line) and the Laschamp run (dashed line). The same zonal mean ${ }^{10} \mathrm{Be}$ production fluxes divided into stratospheric and tropospheric components (bottom).

the Max-Planck Institute for Meteorology, Hamburg, evolving originally from the European Centre of Medium Range Weather Forecasts (ECWMF) spectral weather prediction model. It solves the prognostic equations for vorticity, divergence, surface pressure and temperature, expressed in terms of spherical harmonics with a triangular truncation. Nonlinear processes and physical parametrizations are solved on a Gaussian grid. A complete description of the ECHAM5 GCM is given in Roeckner et al. (2003). The additional aerosol module HAM includes the microphysical processes, the emission and deposition (wet and dry) of aerosols, a sulfur chemistry scheme and aerosol impact radiation (Stier et al., 2005). For this study a middle-atmospheric model version with a horizontal resolution of T42 $(2.8 \times 2.8$ degrees $)$ with 39 vertical levels up to $0.01 \mathrm{hPa}(\sim 60 \mathrm{~km})$ was used.
Table 1. Global budgets of ${ }^{10} \mathrm{Be}$ ( $g=$ gram, $d=$ day)

\begin{tabular}{lccc}
\hline & Control run & Laschamp run & unit \\
\hline Production & 0.19 & 0.40 & $\mathrm{~g} / \mathrm{d}$ \\
Prod. str./tr. & 1.9 & 1.7 & \\
Wet deposition & 0.17 & 0.37 & $\mathrm{~g} / \mathrm{d}$ \\
Dry deposition & 0.02 & 0.03 & $\mathrm{~g} / \mathrm{d}$ \\
Burden str. & 27 & 81 & $\mathrm{~g}$ \\
Burden tr. & 4 & 10 & $\mathrm{~g}$ \\
Residence time str. & 230 & 320 & $\mathrm{~d}$ \\
Residence time tr. & 23 & 25 & $\mathrm{~d}$ \\
Residence time tot. atm. & 170 & 230 & $\mathrm{~d}$ \\
\hline
\end{tabular}

Each run was allowed to spin up for five years to let ${ }^{10} \mathrm{Be}$ reach equilibrium and the five following years were used for the analysis. The run was forced with prescribed observational sea surface temperatures and sea ice cover obtained from the international model intercomparison AMIP2 project.

The production rates of the radionuclides were taken from the revised production rate calculations of Masarik and Beer, submitted. The profiles were interpolated as a function of latitude and altitude using the monthly mean solar modulation function $\Phi$ reconstructed by Usoskin et al. (2005) for the years 1986-1990 for the control run. For the Laschamp run a constant $\Phi=700 \mathrm{MeV}$ was used. The deposition of ${ }^{10} \mathrm{Be}$ is divided into wet and dry deposition and sedimentation. Because the ${ }^{10} \mathrm{Be}$ atoms are attached to sulfate aerosols the deposition is calculated relative to sulfate deposition. For calculating the dry deposition and sedimentation velocity of ${ }^{10} \mathrm{Be}$ an area weighted average of the velocity of sulfate aerosols is used. For the wet deposition of ${ }^{10} \mathrm{Be}$ we assume that ${ }^{10} \mathrm{Be}$ is scavenged with the same efficiency as the sulfate aerosols. See Heikkilä et al. (2008a) for more details. Globally dry deposition accounts for less than $10 \%$ of the total deposition. In Greenland the precipitation rates are relatively high which is why the model suggests a low contribution of dry deposition of less than $10 \%$. Only in the driest areas in Antarctica the dry deposition becomes more important and can be even more than 50\% (see Fig. 5.27 and 5.28 of Heikkilä, 2007). For the two experiments of this study the deposition scheme was the same because the climate was kept constant and therefore the sulfate emissions and concentrations were not influenced.

ECHAM5-HAM's ability to reproduce the observed concentrations and deposition fluxes of ${ }^{10} \mathrm{Be}$ and ${ }^{7} \mathrm{Be}$ worldwide has been discussed in Heikkilä et al. (2008a). We refer to Figs. 2, 3, 4, 5 and 6. Generally the model was able to reproduce both the observed concentrations and deposition fluxes fairly well. Especially in Greenland the agreement was good when reproducing observed fluxes during a Greenlandic traverse (see Fig. 5 in Heikkilä et al. (2008a)) and also the seasonal changes during a 5-year period at Summit, 


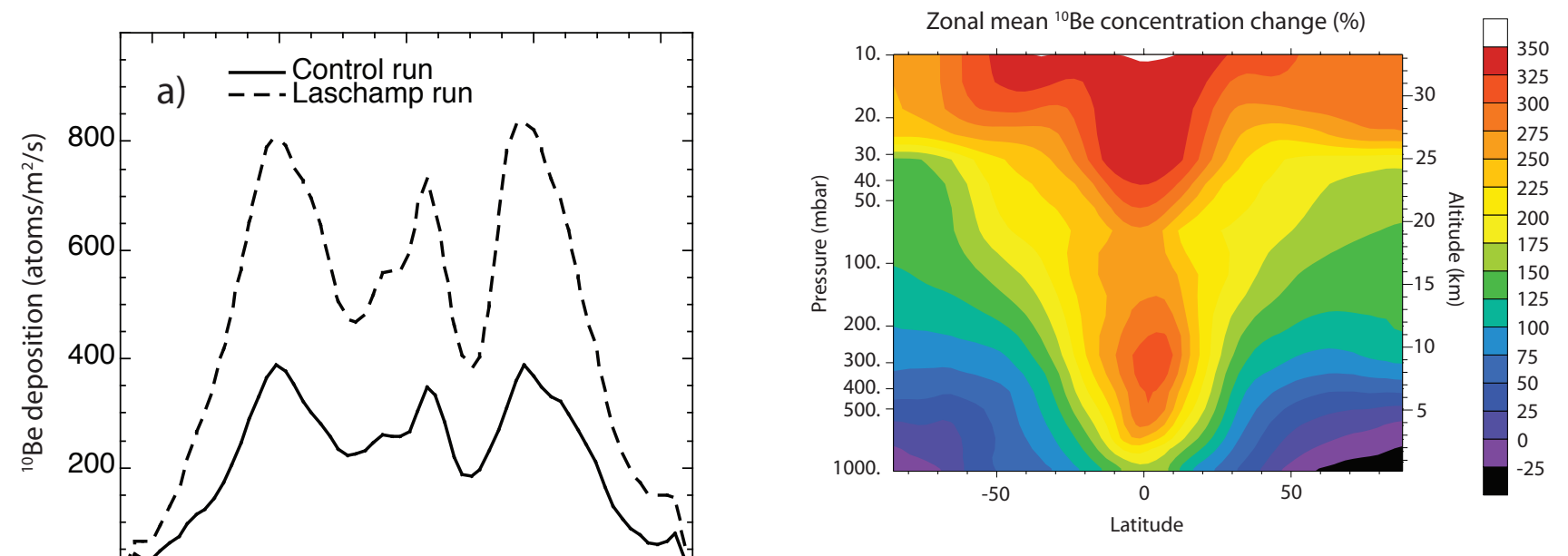

Fig. 3. The zonal mean concentration change in the Laschamp run from the control run in percent.

Greenland (Heikkilä et al., 2008b). Unfortunately not much present day ${ }^{10} \mathrm{Be}$ data is available from Antarctica. Pedro et al. (2006) measured the snow concentrations of ${ }^{10} \mathrm{Be}$ in a snow pit from the Law Dome station in the year 2001. Using their average snow accumulation rate we estimate an average deposition flux of ${ }^{10} \mathrm{Be}$ of $\sim 100$ atoms $/ \mathrm{m}^{2} / \mathrm{s}$, which is comparable with the modeled value of $\sim 150$ atoms $/ \mathrm{m}^{2} / \mathrm{s}$ for the average of 1986-1990.

\section{Results}

\subsection{Total deposition and concentration}

Global budgets of ${ }^{10} \mathrm{Be}$ in both runs are listed in Table 1 . The production rate of ${ }^{10} \mathrm{Be}$ in the Laschamp run is approximately twice as high as in the control run. The ratio of stratospheric to tropospheric production is almost unchanged (Laschamp run 1.7, control run 1.9). The stratospheric burden in the Laschamp run has increased relatively more than the production rate because of the very different distribution of ${ }^{10} \mathrm{Be}$ production. This is also reflected by the longer residence time of ${ }^{10} \mathrm{Be}$ in the stratosphere (320 days in the Laschamp run, 230 days in the control run).

Figure 1 illustrates the zonal mean production rate of ${ }^{10} \mathrm{Be}$ which has been integrated over all longitudes, integrated over the whole atmospheric depth in the upper part of the figure and below it integrated over the stratospheric and the tropospheric depths separately. It can be seen that the production does not change pole-wards of $60^{\circ}$. Instead, in the equatorial region the production rate is increased by a factor of $4-5$ in the Laschamp run. The decrease of the production flux in the southern high latitudes which is not visible in the northern high latitudes is caused by the high altitude of the Antarctic continent with lower air pressure. Although the production is constant at all latitudes, the separate stratospheric 
Origin of the ${ }^{10} \mathrm{Be}$ deposition fluxes (atoms $/ \mathrm{m}^{2} / \mathrm{s}$ )
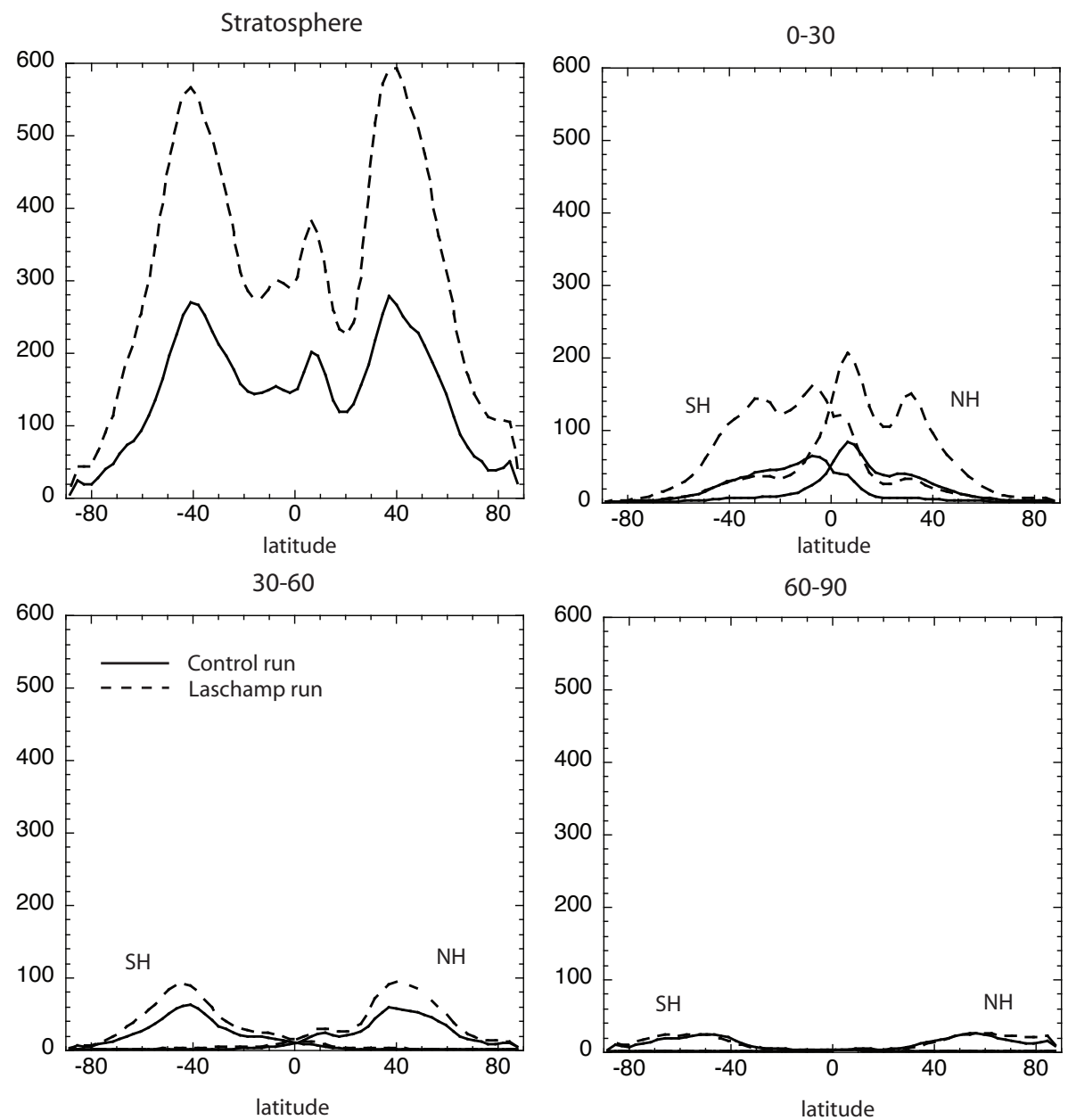

Fig. 4. Zonal means of the different ${ }^{10} \mathrm{Be}$ source region components of the deposition fluxes shown separately in the control run (solid line) and the Laschamp run (dashed line). Above: stratospheric fraction and tropospheric tropical fraction $\left(0-30^{\circ}\right)$, below: tropospheric subtropical fraction $\left(30-60^{\circ}\right)$ and tropospheric polar fraction $\left(60-90^{\circ}\right)$, both Northern $(\mathrm{NH})$ and Southern $(\mathrm{SH})$ Hemisphere shown in the same figure. Units are atoms $/ \mathrm{m}^{2} / \mathrm{s}$.

and the tropospheric production fluxes are not because the tropopause pressure is higher in polar latitudes and lower in the tropics. In the control run the tropospheric production of ${ }^{10} \mathrm{Be}$ has practically no latitudinal dependence because the latitudinal structure of the tropopause height compensates the production structure. The ${ }^{10} \mathrm{Be}$ produced in the stratosphere can be assumed to be quite well mixed due to its long residence time and therefore changes in the stratospheric production are not expected to have an impact on the latitudinal ${ }^{10} \mathrm{Be}$ deposition. On the other hand the much larger tropical tropospheric production might increase the deposition fluxes locally.

However, the zonal mean total deposition fluxes (including wet and dry deposition and sedimentation) of ${ }^{10} \mathrm{Be}$, shown in Fig. 2, in absolute as well as in normalised units show no such difference in the latitudinal distribution. The absolute fluxes are about a factor of 2 higher due to higher production rate (twice as high globally) in the Laschamp run, but the normalised fluxes are practically identical. Especially in the polar regions there is no enhancement. Figure 2 also depicts the deposition change in percent between the Laschamp run and the control run. For comparison we also show the change between the Maunder Minimum experiment (Heikkilä et al., 2008a), which included a climate cooling, and the control run. This change in the Maunder Minimum experiment is mostly below $8 \%$ while the global production change is $32 \%$. The change is slightly larger in the Laschamp experiment, mostly below $10 \%$ and at some points below $20 \%$ of the global mean production raise of $100 \%$. At some points in the high polar latitudes the change is larger than that, both in 
Stratospheric burden $\left(10^{10}\right.$ atoms $\left./ \mathrm{m}^{2}\right)$

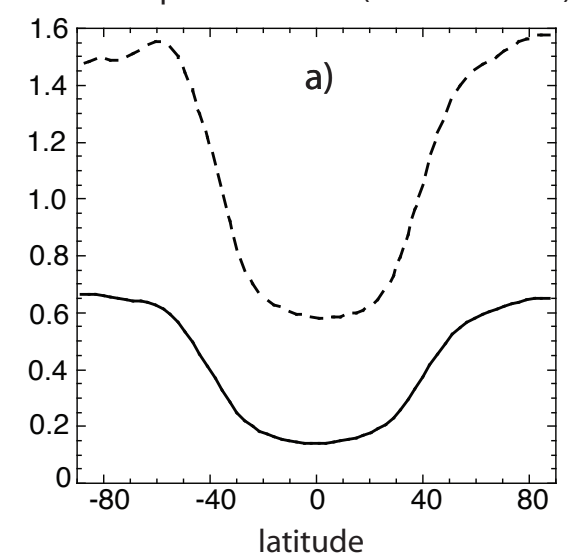

Tropospheric burden $\left(10^{9}\right.$ atoms $\left./ \mathrm{m}^{2}\right)$

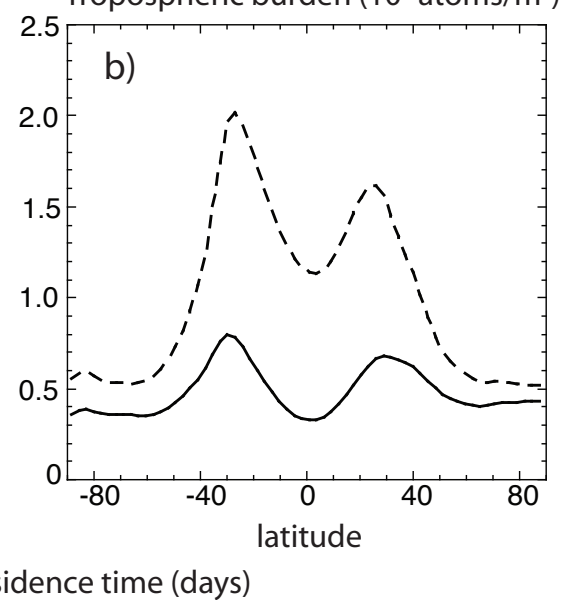

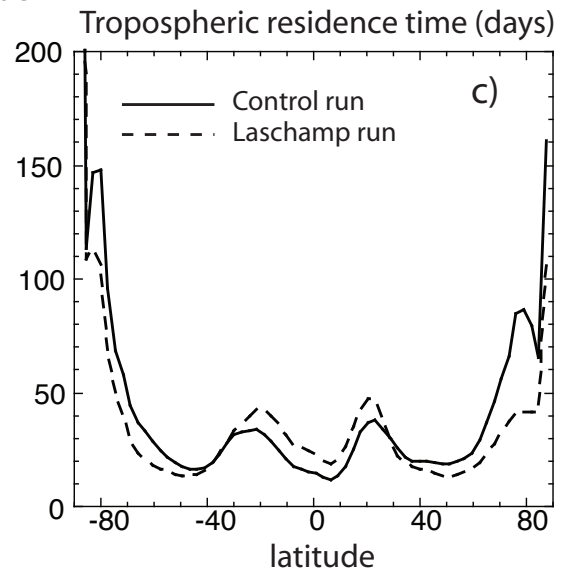

Fig. 5. (a) Zonal mean stratospheric and tropospheric burdens of ${ }^{10} \mathrm{Be}$ in the control run (solid line) and the Laschamp run (dashed line). (b) Tropospheric residence times of ${ }^{10} \mathrm{Be}$ in the control run (solid line) and the Laschamp run (dashed line). (c) The tropospheric residence time, defined as the tropospheric burden divided by the deposition flux.

the Maunder Minimum and the Laschamp experiment. However, if we look at the differences of the normalised deposition fluxes at these latitudes we see that the fluctuations can be considered as negligible. Because the fluxes in the polar regions are extremely low, even small fluctuations account for a larger relative change. This cannot be connected to a polar enhancement which refers to a clear latitudinal change reflecting the latitudinal production change because the fluctuations seen in Fig. 2 can be positive or negative and show no latitudinal pattern similar to the production change. Such small changes could also be caused by different realizations of actual weather between the two runs. Generally these results suggest that independent of the latitudinal distribution of the ${ }^{10} \mathrm{Be}$ production or the climate conditions the distribution of the ${ }^{10} \mathrm{Be}$ deposition fluxes remains the same and reflects clearly the production raise.

The reason for the unchanged normalised ${ }^{10} \mathrm{Be}$ flux is the constant climate between both experiments. The scavenging of ${ }^{10} \mathrm{Be}$ in the model study is connected with sulfate scavenging because we assume that ${ }^{10} \mathrm{Be}$ atoms are attached to sulfate aerosols (Heikkilä et al., 2008a). A scavenging efficiency which depends on the sulfate scavenging efficiency is calculated for ${ }^{10} \mathrm{Be}$. Because the meteorology in both runs was unchanged the sulfate scavenging efficiency remains constant between the control and the Laschamp run and also the relative amount of scavenged ${ }^{10} \mathrm{Be}$ remains unchanged. The ${ }^{10} \mathrm{Be}$ atoms produced in the tropics above the cloud level in the Laschamp run are not scavenged and hence reside longer in the troposphere, as is reflected by the longer tropospheric residence times (discussed in Chapter 3.2), or rise to the stratosphere.

Figure 3 illustrates the change in the zonal mean concentrations of ${ }^{10} \mathrm{Be}$ in air. The change has been calculated in percent from the concentrations in the Laschamp run, compared with the control run. The change is almost always positive because of the approximately doubled production rate in the Laschamp run compared with the control run. We see that the change is largest in the tropics as expected due to the larger production raise there. At high altitudes the concentration change is very large because the high concentrations 
of ${ }^{10} \mathrm{Be}$ in the upper troposphere which are not scavenged are raised to the stratosphere by the Brewer-Dobson circulation and therefore increase the stratospheric concentrations more. At high latitudes in the troposphere the change is quite small $(<100 \%)$ because there the production rate did not change and also reflects the fact that only a small amount of ${ }^{10} \mathrm{Be}$ atoms reach the high latitudes. This will be further discussed in the following paragraphs.

To further investigate the transport paths of ${ }^{10} \mathrm{Be}$ we show the different components of the ${ }^{10} \mathrm{Be}$ deposition fluxes in Fig. 4. The components are ${ }^{10} \mathrm{Be}$ produced in the stratosphere, in the tropical $\left(0-30^{\circ}\right)$, subtropical $\left(30^{\circ}-60^{\circ}\right)$ and polar $\left(60^{\circ}-90^{\circ}\right)$ troposphere, Northern and Southern Hemisphere separately. The sum of all these components is the total deposition flux shown in Fig. 2. It is clear that the dominant component is the stratospheric ${ }^{10} \mathrm{Be}$. The tropospheric components somewhat increase the deposition fluxes locally, but their contribution is not large. Especially the contribution of polar tropospheric $\left(60^{\circ}-90^{\circ}\right)$ production is very low, a result which is not consistent with earlier assumption that ${ }^{10} \mathrm{Be}$ measured in polar regions mostly originates from high latitudes, i.e. Bard et al. (1997).

This result also suggests that changes in the location of the geomagnetic pole, the so-called polar wander, brought up by McCracken (2004b), would not be of importance. The largest contribution to the deposition fluxes is the stratospheric fraction, which is mixed to such an extent that changes in the location of the geomagnetic pole can be neglected.

These results are somewhat different from the findings of Field et al. (2006), who detected an additional $20 \%$ reduction of the deposition fluxes pole-wards of $30^{\circ}-40^{\circ}$ and an increase of up to $60 \%$ in the equatorial region in their reduced geomagnetic field strength experiment although the geomagnetic reduction was only $25 \%$ from the present day strength. We found no latitudinal pattern in the deposition change and generally the fluctuations from the global mean change was much smaller than theirs (Fig. 2), although we reduced the geomagnetic field strength to zero. Their strong latitudinal dependence of the change seems to reflect quite directly the production changes in the tropics, being higher at low latitudes where the production due to geomagnetic reduction is enhanced. At high latitudes they find an increase of only $8 \%$ while the global mean production increase is $10 \%$, which does not reflect the production change because the production rate did not change pole-wards of $60^{\circ}$.

It is not possible to explain the differences between the two models without having more information of the transport paths and the distribution of the ${ }^{10} \mathrm{Be}$ production between the stratosphere and the troposphere in the GISS model used by Field et al. (2006). A known difference between the models is that for the runs of the present work we used the middle atmosphere version with 39 vertical layers, reaching up to $0.01 \mathrm{hPa}$ including the whole stratosphere. The model runs by Field et al. (2006) used a model version with 22 vertical
Stratospheric fraction of the ${ }^{10} \mathrm{Be}$ deposition fluxes
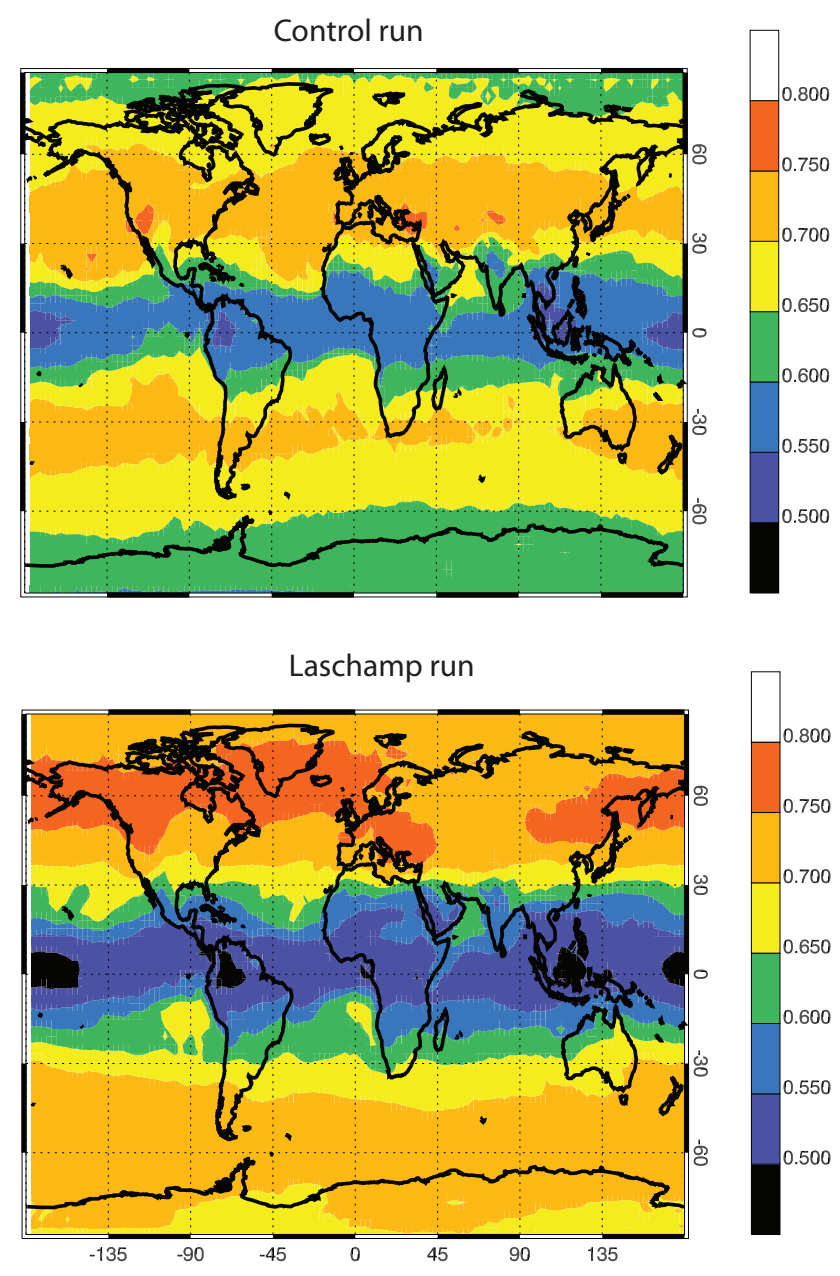

Fig. 6. 2-D fraction (-) of the stratospheric source of ${ }^{10} \mathrm{Be}$ in the total deposition fluxes in the control run (above) and the Laschamp run (below).

layers. This may lead to differences in the atmospheric distribution and residence times of ${ }^{10} \mathrm{Be}$. The too rapid downward transport from the stratosphere to the troposphere is a known weakness of ECHAM5-HAM (Timmreck et al., 1999) and is reflected by the relatively short (less than one year) stratospheric residence times of ${ }^{10} \mathrm{Be}$ in Table 1 . It is caused by the too coarse vertical resolution in the tropopause region (Timmreck et al., 1999). The average atmospheric residence time of ${ }^{10} \mathrm{Be}$ has been determined to be $1-2$ years (Raisbeck et al., 1987). Earlier studies made by ECHAM5HAM's standard version with 31 vertical levels revealed that this residence time was largely underestimated, being in the order of 8 months. Using the middle atmospheric version of ECHAM5-HAM with 39 vertical levels increases the stratospheric residence time slightly but, what is more important, the stratospheric transport is better described. This has an 

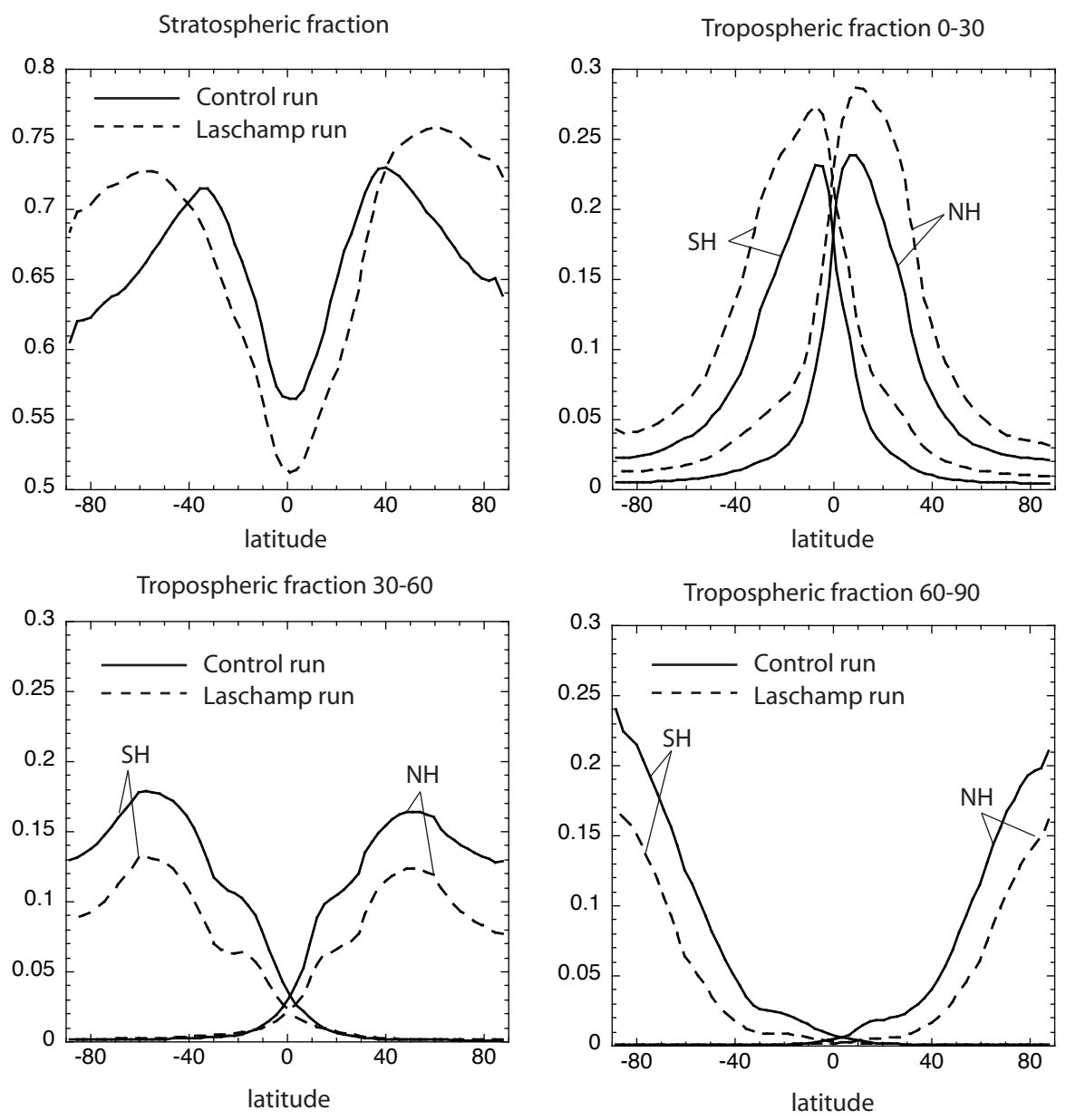

Fig. 7. Fractions of the different source regions of the ${ }^{10} \mathrm{Be}$ deposition fluxes: stratospheric production, tropospheric tropical production $\left(0-30^{\circ}\right)$, subtropical production $\left(30-60^{\circ}\right)$ and polar $\left(60-90^{\circ}\right)$, both in the Northern $(\mathrm{NH})$ and the Southern $(\mathrm{SH})$ Hemisphere in the control run (solid line) and the Laschamp run (dashed line).

important impact on the ${ }^{10} \mathrm{Be}$ concentrations in the tropospheric air, and therefore it probably also influences the distribution of the ${ }^{10} \mathrm{Be}$ deposition.

Another difference between the models is the horizontal resolution used $\left(4^{\circ}-5^{\circ}\right.$ in the GISS model, $2^{\circ}-3^{\circ}$ in ECHAM5-HAM). A coarser horizontal resolution is known to cause numerical diffusion which leads to a larger transport of species towards high latitudes. Both models differ very largely in this sense. 16 different models were compared in the AeroCom model comparison experiment (Textor et al., 2006). The fraction of sulfate aerosol transported to polar latitudes (pole-ward of $80^{\circ}$ ) was investigated. The fraction of sulfate transported to polar latitudes in the GISS model was among the largest (10-11\%) of all models whereas in the ECHAM5 model the fraction was among the smallest (2\%), see Figs. 10 and 12 of Textor et al. (2006). This difference however does not explain the modeled polar enhancement by the GISS model because their deposition flux reflects very directly the local production change.

\subsection{Burdens and residence times}

Figure 5 illustrates the stratospheric and tropospheric burdens of ${ }^{10} \mathrm{Be}$ and the respective residence times. The residence time for ${ }^{10} \mathrm{Be}$ in the troposphere is defined as the tropospheric burden divided by total deposition.

The latitudinal distribution of the burdens of ${ }^{10} \mathrm{Be}$ in both the stratosphere and the troposphere shows no large changes. The stratospheric burden in the Laschamp run reflects the tropopause height because the production rate is constant at all latitudes. In the control run the larger stratospheric burden at high latitudes is connected to the higher production rate there which is reflected by the symmetry between the Northern and Southern Hemisphere unlike in the Laschamp run.

In the tropospheric low latitudes the burden is clearly increased in the Laschamp run due to the much higher production rate of ${ }^{10} \mathrm{Be}$ there. The residence time in the troposphere is higher by $\sim 5$ days equator-ward of $40^{\circ}$ in the Laschamp 
run which causes the tropospheric tropical burden of ${ }^{10} \mathrm{Be}$ to increase. Pole-ward of $40^{\circ}$ the residence time is slightly shorter. At high latitudes pole-ward of $70^{\circ}$ the residence time becomes much longer reflecting the lower precipitation rates in the polar regions and therefore the increased residence of the ${ }^{10} \mathrm{Be}$ atoms in the troposphere.

\subsection{Stratospheric fractions}

We have noted that the most important contribution of ${ }^{10} \mathrm{Be}$ to the deposition fluxes is from the stratosphere. Figure 6 shows the 2-D field of the stratospheric fraction of the ${ }^{10} \mathrm{Be}$ deposition fluxes in the control run (above) and in the Laschamp run (below). It seems that the stratospheric fraction is relatively constant zonally. The largest fractions occur in the mid-latitudes. In the Laschamp run the area of largest fraction is shifted towards the poles. The stratospheric fraction in the tropics is lower in the Laschamp run than in the control run due to the larger tropical tropospheric production.

Figure 7 shows the zonal means of the same stratospheric fractions as the Fig. 6, as well as the fractions of the tropospheric production bands. These fractions show partly significant changes. As mentioned earlier, the stratospheric fraction in the Laschamp run is lower in the tropics due to higher tropical production. Because the fraction of stratospheric production of the total production is globally $65 \%$ the stratospheric fraction has to be higher at high latitudes, pole-wards of $40^{\circ}-50^{\circ}$, to compensate for the lower fractions in the tropics. The production changes in the troposphere cause the fractions to change only locally. The higher tropical production in the Laschamp run increases the tropical fractions slightly (less than 5\%) at all latitudes, but mostly in the tropics. The subtropical fraction and the polar fraction are reduced in the Laschamp run because of the increased stratospheric fraction at those latitudes. The changes are very similar in both hemispheres. The stratospheric fraction is slightly larger in the Northern Hemisphere due to the stronger stratosphere-troposphere exchange there (Holton et al., 1995; Stohl et al., 2003).

The exact fractions of the components of the ${ }^{10} \mathrm{Be}$ deposition fluxes at some of the most important ice core sites in Greenland and Antarctica are listed in Table 2. First, the total deposition fluxes are listed in the control run and the Laschamp run showing that the increase in the ${ }^{10} \mathrm{Be}$ deposition is approximately $100 \%$ at all sites consistently with the production raise in the Laschamp run. These fluxes cannot be compared with present day observations from the ice core sites due to lack of data. We refer to Heikkilä et al. (2008a) for a comparison with the ${ }^{10} \mathrm{Be}$ ice core concentrations during the Maunder Minimum. Generally the modelled concentrations agreed well with the measured ones in Greenland but were too low by a factor of 2 in Antarctica due to somewhat high modelled precipitation rates at the driest Antarctic sites.

An encouraging result for the use of ${ }^{10} \mathrm{Be}$ in ice cores is the fact that the relative contributions of ${ }^{10} \mathrm{Be}$ from the different

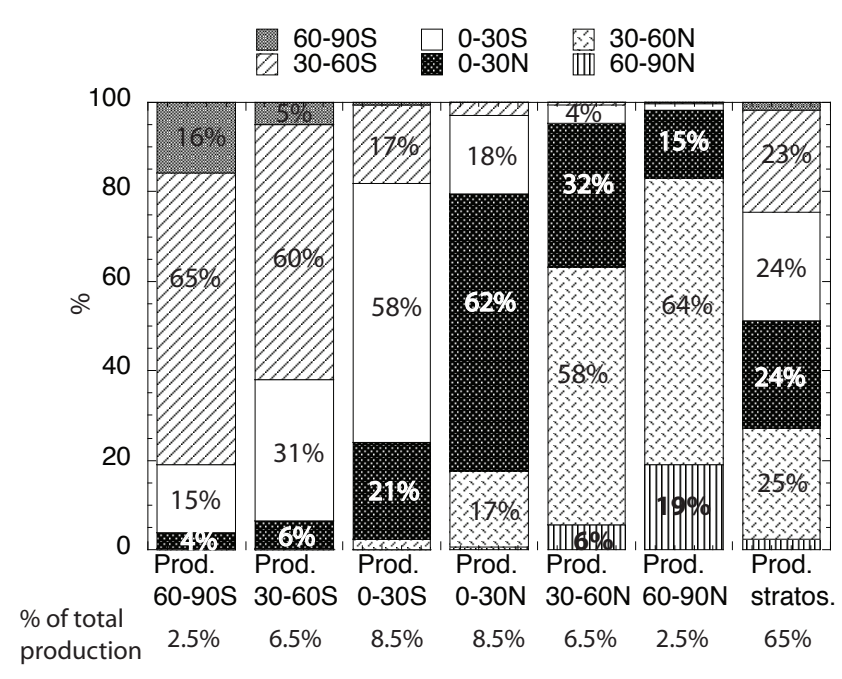

Fig. 8. This figure shows at which latitudes the ${ }^{10} \mathrm{Be}$, produced at a given part of the atmosphere (x-axis), is deposited (y-axis). For example: ${ }^{10} \mathrm{Be}$ produced in the troposphere between $60-90^{\circ} \mathrm{S}$ is deposited to $16 \%$ between $60-90^{\circ} \mathrm{S}$, to $65 \%$ between $30-60^{\circ} \mathrm{S}$ and to $15 \%$ between $0-30^{\circ} \mathrm{S}$ (see the leftmost stack). This figure illustrates the division in the control run. The Laschamp run is not shown because the division is quite similar, please refer to Table 3 for the exact figure.

source regions are quite constant between both experiments. In Greenland, in the control run the stratospheric fraction in the deposition fluxes is approximately $70 \%$, and half of the rest originates from the tropospheric subtropics and the other half from polar latitudes. The contribution of ${ }^{10} \mathrm{Be}$ produced in the tropics or the other hemisphere are almost negligible. In Antarctica the fraction of stratospheric source of ${ }^{10} \mathrm{Be}$ is slightly lower than in the Northern Hemisphere, probably due to the weaker stratosphere-troposphere exchange in the Southern Hemisphere. Also the fraction of the local tropospheric production is larger (20-24\%) than in Greenland $(\sim 14 \%)$. This result agrees very well with Mazaud et al. (1994), who estimated that at Vostok drilling site $75 \%$ of the ${ }^{10} \mathrm{Be}$ is transported from lower latitudes (or the stratosphere) and only $25 \%$ is locally produced. The situation is slightly changed in the Laschamp run. The fraction of the stratospheric source is increased in the polar regions, as shown in the earlier section. This reduces slightly the fraction of tropospheric subtropical and polar fraction and increases the tropical fraction by a few percent but the stratospheric component still remains the dominant one. Also the contributions of the tropospheric fractions are unchanged, i.e. the tropical production fraction is very low and the subtropical and polar production contribute approximately equal amounts to the total deposition. 
Table 2. The fractions of the ${ }^{10} \mathrm{Be}$ source region components in the deposition fluxes at some of the Greenlandic and Antarctic drilling sites and globally.

\begin{tabular}{lcccccc}
\hline Control run & GRIP & Milcent & Dye3 & DomeC & South Pole & Global \\
\hline $\begin{array}{l}\text { Tot. dep. } \\
\text { at/m²/s }\end{array}$ & 76 & 101 & 129 & 17 & 7 & 252 \\
& & & & & & \\
0-30 trop. & $3 \%$ & $3 \%$ & $3 \%$ & $2 \%$ & $2 \%$ & $17 \%$ \\
30-60 trop. & $14 \%$ & $14 \%$ & $15 \%$ & $15 \%$ & $13 \%$ & $13 \%$ \\
60-90 trop. & $14 \%$ & $14 \%$ & $13 \%$ & $20 \%$ & $24 \%$ & $5 \%$ \\
stratospheric & $69 \%$ & $69 \%$ & $69 \%$ & $63 \%$ & $61 \%$ & $65 \%$ \\
\hline Laschamp run & GRIP & Milcent & Dye3 & DomeC & South Pole & Global \\
\hline Tot. dep. & 157 & 216 & 305 & 30 & 10 & 524 \\
at/m 2 /s & & & & & & \\
& & & & & & \\
0-30 trop. & $4 \%$ & $5 \%$ & $5 \%$ & $5 \%$ & $5 \%$ & $25 \%$ \\
$30-60$ trop. & $9 \%$ & $9 \%$ & $10 \%$ & $10 \%$ & $10 \%$ & $8 \%$ \\
60-90 trop. & $9 \%$ & $9 \%$ & $7 \%$ & $13 \%$ & $16 \%$ & $3 \%$ \\
stratospheric & $78 \%$ & $77 \%$ & $78 \%$ & $72 \%$ & $69 \%$ & $64 \%$ \\
\hline
\end{tabular}

\begin{tabular}{lccccc}
\multicolumn{5}{l}{ Stratospheric fractions (only available for the Laschamp run): } \\
\hline $60-90$ n strat. & $17 \%$ & $17 \%$ & $17 \%$ & 0 & 0 \\
$30-60$ n strat. & $32 \%$ & $32 \%$ & $32 \%$ & $2 \%$ & $2 \%$ \\
$0-30$ n strat. & $19 \%$ & $19 \%$ & $19 \%$ & $6 \%$ & $6 \%$ \\
$0-30$ s strat. & $7 \%$ & $7 \%$ & $7 \%$ & $17 \%$ & $17 \%$ \\
$30-60$ s strat. & $3 \%$ & $2 \%$ & $3 \%$ & $30 \%$ & $28 \%$ \\
$60-90$ s strat. & 0 & 0 & 0 & $17 \%$ & $16 \%$
\end{tabular}

Table 2 also shows the stratospheric mixing, i.e. the stratospheric source divided into $30^{\circ}$ latitude bands. This division exists only for the Laschamp run. The fractions of the different production regions can probably roughly be generalised to the control run because the latitudinal distribution of the stratospheric burden of ${ }^{10} \mathrm{Be}$ is very similar in both runs (see Fig. 5). This division shows that ${ }^{10} \mathrm{Be}$ is equally mixed in the stratosphere in both hemispheres. Approximately $30 \%$ of the total ${ }^{10} \mathrm{Be}$ deposition comes from the stratospheric midlatitudes whereas the tropical and polar latitude production contribute $16-19 \%$ each. Approximately $10 \%$ of the total ${ }^{10} \mathrm{Be}$ deposition originates from the stratosphere of the opposite hemisphere but the tropospheric contribution of the opposite hemisphere is negligible.

The mass fractions of the ${ }^{10} \mathrm{Be}$ production in different regions are shown in the rightmost column.

\subsection{Atmospheric mixing}

So far we have investigated from which part of the atmosphere the ${ }^{10} \mathrm{Be}$ in ice cores originates. Another interesting question is the destiny of ${ }^{10} \mathrm{Be}$, i.e. at which latitudes the ${ }^{10} \mathrm{Be}$, produced at a given region of the atmosphere, is finally deposited. We calculated the percentages of different latitudes of the deposition with respect to the source re- gions stratosphere and the 30-degree tropospheric production bands (Table 3). An illustration of these percentages in the case of the control run is shown in Fig. 8. Table 3 reads so that below the "Production" the different atmospheric regions (stratosphere or the tropospheric 30-degree bands) are shown and next to them the percentages of ${ }^{10} \mathrm{Be}$ which is deposited at latitudes shown above them. The sum of these percentages is $100 \%$. The numbers in parenthesis show the results of the Laschamp run, the other ones the control run.

These percentages show that the ${ }^{10} \mathrm{Be}$ which is produced both in the polar and the subtropical latitudes is mostly $(\sim 60-65 \%)$ deposited in the subtropics. A similar fraction of the rest $(\sim 15 \%)$ of the polar ${ }^{10} \mathrm{Be}$ is deposited in the polar and tropical latitudes whereas the rest $(\sim 30 \%)$ of the subtropical ${ }^{10} \mathrm{Be}$ is deposited in the tropics and only very little $(\sim 5 \%)$ of it in the polar latitudes. Very little $(2-5 \%)$ of the polar or subtropical ${ }^{10} \mathrm{Be}$ is transported to the opposite hemisphere. The tropical ${ }^{10} \mathrm{Be}$ is mostly $(\sim 60 \%)$ deposited in the tropics. Half of the rest $(\sim 20 \%)$ reaches the tropics of the opposite hemisphere and the other half is deposited in the subtropics. The ${ }^{10} \mathrm{Be}$ which is produced in the stratosphere is quite well mixed within each hemisphere and equally deposited in the tropics and the subtropics $(\sim 25 \%)$. It hardly reaches the polar latitudes $(2-3 \%)$ reflecting the strongest stratosphere-troposphere exchange in 
Table 3. This table shows at which latitudes (in the title of the table) ${ }^{10} \mathrm{Be}$, produced at a given region of the atmosphere (below "Production" in the table), is deposited in the control run. Laschamp run is in parenthesis. The largest differences are printed in bold. See Fig. 8 for the illustration of these percentages.

\begin{tabular}{lcccccc}
\hline & $\begin{array}{c}\text { Deposition } \\
60^{\circ}-90^{\circ} \mathrm{S}\end{array}$ & $30^{\circ}-60^{\circ} \mathrm{S}$ & $0-30^{\circ} \mathrm{S}$ & $0-30^{\circ} \mathrm{N}$ & $30^{\circ}-60^{\circ} \mathrm{N}$ & $60^{\circ}-90^{\circ} \mathrm{N}$ \\
\hline Production & & & & & & \\
$60^{\circ}-90^{\circ} \mathrm{S}$ trop. & $16(22) \%$ & $65(61) \%$ & $15(13) \%$ & $4(4) \%$ & $0 \%$ & $0 \%$ \\
$30^{\circ}-60^{\circ} \mathrm{S}$ trop. & $5(5) \%$ & $58(58) \%$ & $31(29) \%$ & $6(7) \%$ & $0(1) \%$ & $0 \%$ \\
$0-30^{\circ} \mathrm{S}$ trop. & $1(1) \%$ & $17(21) \%$ & $58(50) \%$ & $21(23) \%$ & $3(5) \%$ & $0 \%$ \\
$0-30^{\circ} \mathrm{N}$ trop. & $0 \%$ & $3(6) \%$ & $18(20) \%$ & $62(53) \%$ & $17(20) \%$ & $0(1) \%$ \\
$30^{\circ}-60^{\circ} \mathrm{N}$ trop. & $0 \%$ & $1(1) \%$ & $4(5) \%$ & $32(28) \%$ & $58(60) \%$ & $5(6) \%$ \\
$60^{\circ}-90^{\circ} \mathrm{N}$ trop. & $0 \%$ & $0 \%$ & $2(2) \%$ & $15(9) \%$ & $64(62) \%$ & $19(27) \%$ \\
stratospheric & $2(2) \%$ & $23(24) \%$ & $24(23) \%$ & $24(22) \%$ & $25(26) \%$ & $2(3) \%$ \\
\hline
\end{tabular}

the subtropical latitudes. Although only a negligible part of the stratospheric ${ }^{10} \mathrm{Be}$ is deposited in the polar regions, the stratospheric ${ }^{10} \mathrm{Be}$ contributes the most $(\sim 65 \%$, see Table 2$)$ to the total deposition in polar regions, because the absolute deposition in polar regions is low. These distributions in both hemispheres are symmetric.

The destiny of ${ }^{10} \mathrm{Be}$ produced in a given region in the atmosphere does not largely change although the production distribution changes between the control run and the Laschamp run. Some differences between the control and the Laschamp run are introduced by the fact that the tropospheric tropical burden of ${ }^{10} \mathrm{Be}$ is enhanced in the Laschamp run due to the much larger tropospheric tropical production rate. In the control run a very large fraction of the ${ }^{10} \mathrm{Be}$, produced in the tropics, is deposited at these latitudes (Northern Hemisphere: $62 \%$, Southern Hemisphere: 58\%). In the Laschamp run these fractions are up to $10 \%$ lower because the tropical production is larger but relatively the same amount of ${ }^{10} \mathrm{Be}$ is scavenged and therefore the tropospheric concentrations are enhanced. The ${ }^{10} \mathrm{Be}$ which stays in the atmosphere is transported towards the mid-latitudes $\left(30^{\circ}-60^{\circ}\right)$, either directly or over the stratosphere, and deposited there. This is reflected by the slightly enhanced fractions of the deposition of the tropically produced ${ }^{10} \mathrm{Be}$ in the latitudes between $30^{\circ}-60^{\circ}$ (Northern Hemisphere: raise from $17 \%$ to $21 \%$, Southern Hemisphere: raise from $17 \%$ to $20 \%$, Table 3).

\section{Summary and conclusions}

In this study we assessed the question of how well the observed ${ }^{10} \mathrm{Be}$ concentrations in ice cores reflect the global production changes. Another issue was to investigate whether we find the so called "polar enhancement", i.e. an enhanced amplitude of the polar deposition of ${ }^{10} \mathrm{Be}$ compared with the global production, which has been widely discussed in the literature. We modelled two periods with a very different latitudinal ${ }^{10} \mathrm{Be}$ production distribution, a present day situation and a geomagnetic minimum (field strength zero, as for example during the Laschamp geomagnetic minimum $40 \mathrm{kyr}$ before present). Because of the total lack of the geomagnetic field the ${ }^{10} \mathrm{Be}$ production has no latitudinal dependence, a strong contrast to the present day situation where the production rate pole-wards of $60^{\circ}$ is up to a factor of 5 larger than in the equatorial area. The global average ${ }^{10} \mathrm{Be}$ production was twice as large in the Laschamp run than in the control run.

A comparison of the zonally averaged deposition fluxes of ${ }^{10} \mathrm{Be}$ gave no indication of a polar enhancement. The latitudinal distribution of the deposition fluxes is very similar in the control run and the Laschamp run, except that in the Laschamp run the fluxes are twice as large than in the control run due to the enhanced global mean production rate. The normalised fluxes show hardly any difference. The relative change of the normalised zonal mean ${ }^{10} \mathrm{Be}$ deposition fluxes has no latitudinal dependence and fluctuates between $\pm 10-20 \%$. Statistically a polar enhancement smaller than this noise level could exist but in that case it should be largest in the tropics where the production rate changes the most. This however is not the case. When comparing the simulated deposition flux change from another ${ }^{10} \mathrm{Be}$ run during a solar minimum, the Maunder Minimum, which also included a climate cooling (Heikkilä et al., 2008a), the change from the control run is very similar and mostly below $10 \%$ in both experiments. These results suggest that the deposition fluxes of ${ }^{10} \mathrm{Be}$ reflect well the changes in the global average ${ }^{10} \mathrm{Be}$ production rate. However, it must be kept in mind that the climatic conditions add to the variability so that the observed ${ }^{10} \mathrm{Be}$ deposition fluxes reflect a larger production variability than the global average production. The cooling during the Maunder Minimum was estimated to cause climatic fluctuations of less than $25 \%$ of the production change (Heikkilä et al., 2008a). Another study, which compared ${ }^{10} \mathrm{Be}$ and ${ }^{14} \mathrm{C}$ records using a statistical method to identify a common component in both data sets, estimated the climatic fluctuations to be less than $10 \%$ on time scales of 100 years (Beer et al, 2007). 
We divided the ${ }^{10} \mathrm{Be}$ production into different atmospheric source regions to be able to trace back the origin of the ${ }^{10} \mathrm{Be}$ in polar regions. The most important source region is the stratosphere, where we can assume ${ }^{10} \mathrm{Be}$ to be quite well mixed within each hemisphere during the residence time of ${ }^{10} \mathrm{Be}$ of $1-2$ years. The fraction of stratospheric ${ }^{10} \mathrm{Be}$ in the zonal mean deposition fluxes did not vary significantly, between 0.5 (equator) and $0.7\left(30^{\circ}-60^{\circ}\right)$. At the main ice core drilling sites in Greenland the fraction is approximately $70 \%$ and slightly lower at approximately $60 \%$ in Antarctica reflecting the less efficient stratosphere-troposphere exchange in the Southern Hemisphere. In the Laschamp run these fractions were slightly enhanced. The ${ }^{10} \mathrm{Be}$ produced in the tropics practically does not reach the polar regions (fraction 2$5 \%$ ). The fractions of the subtropical and polar tropospheric production of ${ }^{10} \mathrm{Be}$ are equally large $(\sim 15 \%)$ in the Arctic deposition fluxes. In Antarctica the fraction of locally (polar tropospheric) produced ${ }^{10} \mathrm{Be}$ is slightly larger $(15-20 \%)$ than the subtropical fraction (10\%).

We also investigated at which latitudes the ${ }^{10} \mathrm{Be}$, produced at a given atmospheric region, is finally deposited. The stratospheric ${ }^{10} \mathrm{Be}$ is equally deposited in the subtropics and tropics but only a very small fraction of it $(2 \%)$ is deposited at polar latitudes. The polar tropospheric ${ }^{10} \mathrm{Be}$ is mostly deposited in the subtropics as well as the subtropical ${ }^{10} \mathrm{Be}$. The tropical ${ }^{10} \mathrm{Be}$ is mostly deposited in the tropics. However, because the absolute stratospheric production rate is much larger than the polar tropospheric production rate, the absolute amount of stratospheric ${ }^{10} \mathrm{Be}$ in polar regions is still the dominant component in the deposition flux. The differences in this atmospheric mixing between the control run with present day ${ }^{10} \mathrm{Be}$ production and the geomagnetic minimum, the "Laschamp" run, are not very large pointing that the atmospheric mixing of ${ }^{10} \mathrm{Be}$ is independent of production in a constant climate.

The fact that the ${ }^{10} \mathrm{Be}$ in the stratosphere is mixed in each hemisphere independent of its original distribution also applies to other long-lived nuclides, such as ${ }^{36} \mathrm{Cl}$ or ${ }^{26} \mathrm{Al}$, to the volcanic debris and the bomb-test produced peaks of ${ }^{90} \mathrm{Sr}$ and ${ }^{137} \mathrm{Cs}$. The very different latitudinal production distribution in the Laschamp run changed mainly the concentrations of tropospheric tropical ${ }^{10} \mathrm{Be}$, which is rapidly scavenged from the air before it is transported to higher latitudes. The fact that the stratospheric hemispherically well mixed fraction of ${ }^{10} \mathrm{Be}$ is the dominant component in the ${ }^{10} \mathrm{Be}$ deposition fluxes world-wide gives confidence to the earlier assumption that ${ }^{10} \mathrm{Be}$ in the deposition fluxes reflects the global production rate (Muscheler et al., 2007; Vonmoos et al., 2006).

Acknowledgements. We are grateful to the German Computer Centre (DKRZ) for providing us with the computing time. This project was financially supported by the NCCR Climate.

Edited by: T. Röckmann

\section{References}

Bard, E., Raisbeck, G., Yiou, F., and Jouzel, J.: Solar modulation of cosmogenic nuclide production over the last millennium: comparison between ${ }^{14} \mathrm{C}$ and ${ }^{10} \mathrm{Be}$ records, Earth and Planetary Science Letters, 150, 453-462, 1997.

Baumgartner, S., Beer, J., Masarik, J., Wagner, G., Meynadier, L., and Synal, H.-A.: Geomagnetic Modulation of the ${ }^{36} \mathrm{Cl}$ flux in the GRIP ice core, Greenland, Science, 279, 1330-1332, 1998.

Beer, J., Andrée, M., Oeschger, H., Siegenthaler, U., Bonani, G., Hofmann, H., Morenzoni, E., Nessi, M., Suter, M., Wölfli, W., Finkel, R., and Langway, Jr. C.: The Camp Century ${ }^{10}$ Be ice core record: implications for long-term variations of the geomagnetic dipole moment, Nucl. Instrum. Meth., B5, 380-384, 1984.

Beer, J., Bonani, G., Hofmann, H., Suter, M., Synal, H. A., Wölfli, W., Oescher, H., Siegenthaler, U., and Finkel, R.: ${ }^{10}$ Be measurements on polar ice: comparison of Arctic and Antarctic records, Nucl. Instrum. Meth., B29, 380-384, 1987.

Beer, J., Siegenthaler, U., and Blinov, A.: Temporal ${ }^{10}$ Be variations in ice: information on solar activity and geomagnetic field intensity, Secular Solar and Geomagnetic Variartions in the Last 10’000 Years, by Kluwer Academic Publishers, 297-313, 1988.

Beer, J., McCracken, K., Abreu J., Heikkilä, U., and Steinhilber, F.: Long-term changes in cosmic rays derived from cosmogenic radionuclides, ICRC 2007 Proceedings, Merida, Mexico, 2007.

Field, C., Schmidt, G., Koch, D. and Salyk, C.: Modeling production and climate-related impacts on ${ }^{10} \mathrm{Be}$ concentration in ice cores, J. Geophys. Res., 111, D15107, doi:10.1029/2005JD00640, 2006.

Heikkilä, U.: Modelling of the atmospheric transport of the cosmogenic radionuclides ${ }^{10} \mathrm{Be}$ and ${ }^{7} \mathrm{Be}$ using the ECHAM5-HAM general circulation model, Dissertation ETH No. 17516, online available at: http://e-collection.ethbib.ethz.ch, 2007.

Heikkilä, U., Beer, J., and Feichter, J.: Modeling cosmogenic radionuclides ${ }^{10} \mathrm{Be}$ and ${ }^{7} \mathrm{Be}$ during the Maunder Minimum with the general circulation model ECHAM5-HAM, Atmos. Chem. Phys., 8, 2797-2809, 2008a,

http://www.atmos-chem-phys.net/8/2797/2008/.

Heikkilä, U., Beer, J., Jouzel, J., Feichter, J., and Kubik, P.: ${ }^{10} \mathrm{Be}$ measured in a GRIP snow pit and modeled using the ECHAM5-HAM general circulation model, Geophys. Res. Lett., 35, L05817, doi:10.1029/2007GL033067, 2008b.

Holton, J., Haynes, P., McIntyre, M., Douglass, A., Rood, R., and Pfister, L.: Stratosphere-troposphere exchange, Rev. Geophys., 33, 403-439, 1995.

Lal, D. and Peters, B., Cosmic ray produced radioactivity on the Earth, Handbuch der Physik, Springer-Verlag, New York, USA, XLVI/2, 551-612, 1967.

Masarik, J. and Beer, J.: Simulation of particle fluxes and cosmogenic nuclide production in the Earth's atmosphere, J. Geophys. Res., 104, 12099-12111, 1999.

Mazaud, A., Laj, C., and Bender, M.: A geomagnetic chronology for antarctic ice accumulation, Geophys. Res. Lett., 21(5), 337340, 1994.

McCracken, K., McDonald, F., Beer, J., Raisbeck, G., and Yiou, F.: A phenomenological study of the long-term cosmic ray modulation, 850-1958 AD, J. Geophys. Res. 109, A12103, doi:1029/2005JA10685, 2004a.

McCracken, K.: Geomagnetic and atmospheric effects upon the cosmogenic ${ }^{10} \mathrm{Be}$ observed in polar ice, J. Geophys. Res., 109, 
A04101, doi:10.1029/2003JA010060, 2004b.

Muscheler, R., Joos, F., Beer, J., Müller, S., Vonmoos, M., and Snowball, I.: Solar activity during the last $1000 \mathrm{yr}$ inferred from radionuclide records, Quarternary Sci. Rev., 26, 82-97, 2007.

Pedro, J., van Ommen, T., Curran, M., Morgan, V., Smith, A., and McMorrow, A.: Evidence for climate modulation of ${ }^{10}$ Be solar activity proxy, J. Geophys. Res., 111, D21105, doi:10.1029/2005JD006764, 2006.

Raisbeck, G., Yiou, F., Bourles, D., Lorius, C., Jouzel, J. and Barkov, N. I.: Evidence for two intervals of enhanced ${ }^{10} \mathrm{Be}$ deposition in Antarctic ice during the last glacial period, Nature, 326, 273-277, 1987.

Roeckner, E., Baeuml, G., Bonventura, L., Brokopf, R., Esch, M., Giorgetta, M., Hagemann, S., Kirchner, I., Kornblueh, L., Manzini, E., Rhodin, A., Schlese, U., Schulzweida, U., and Tompkins, A.: The atmospheric general circulation model ECHAM5. PART I: Model description, Report 349, Max Planck Institute for Meteorology, Hamburg, Germany, online available at: http://www.mpimet.mpg.de, 2003.

Steig, E., Polissar, P., Stuiver, M., Grootes, P., and Finkel, R.: Large amplitude solar modulation cycles of ${ }^{10} \mathrm{Be}$ in Antractica: implications for atmospheric mixing processes and interpretation of the ice core record, Geophys. Res. Lett., 23(5), 523-526, 1996.

Stier, P., Feichter, J., Kinne, S., Kloster, S., Vignati, E., and Wilson, J.: Ganzeveld., L., Tegen, I., Werner, M., Schulz, M., Balkanski, Y., Boucher, O., Minikin, A., and Petzold, A.: The aerosolclimate model ECHAM5-HAM, Atmos. Chem. Phys., 5, 11251165, 2005, http://www.atmos-chem-phys.net/5/1125/2005/.

Stohl, A., Bonasoni, P., Cristofanelli, P., Collins, W., Feichter, J., Frank, A., Forster, C., Gerasopoulos, E., Gäggeler, H., James, P., Kentarchos, T., Kromp-Kolb, H., Krüger, B., Land, C., Meloen, J., Papayannis, A., Priller, A., Seibert, P., Sprenger, M., Roelofs, G. J., Scheel, H. E., Schnabel, C., Siegmund, P., Tobler, L., Trickl, T., Wernli, H., Wirth, V., Zanis, P., Zerefos, C.: Stratosphere-troposphere exchange: A review, and what we have learnt from STACCATO, J. Geophys. Res., 108(D12), 8516, doi:10.1029/2002JD002490, 2003.
Textor, C., Schulz, M., Guibert, S., Kinne, S., Balkanski, Y., Bauer, S., Berntsen, T., Berglen, T., Boucher, O., Chin, M., Dentener, F., Diehl, T., Easter, R., Feichter, J., Fillmore, D., Ghan, S., Ginoux, P., Gong, S., Grini, A., Hendricks, J., Horowitz, L., Huang, P., Isaksen, I., Iversen, T., Kloster, S., Koch, D., Kirkevåg, A., Kristjansson, J. E., Krol, M., Lauer, A., Lamarque, J. F., Liu, X., Montanaro, V., Myhre, G., Penner, J., Pitari, G., Reddy, S., Seland, Ø., Stier, P., Takemura, T. and Tie, X.: Analysis and quantification of the diversities of aerosol life cycles within AeroCom, Atmos. Chem. Phys., 6, 1777-1813, 2006, http://www.atmos-chem-phys.net/6/1777/2006/.

Timmreck, C., Graf, H.-F., and Feichter, J.: Simulation of Mt. Pinatubo volcanic aerosol with the Hamburg Climate Model ECHAM4, Theor. Appl. Climatol., 62, 85-108, 1999.

Usoskin, I. G., Alanko-Huotari, K., Kovaltsov, G. A., and Mursula., K.: Heliospheric modulation of cosmic rays: Monthly reconstruction of 1951-2004, J. Geophys. Res. 110, A12108, doi:10.1029/2005JA011250, 2005.

Vonmoos, M., Beer, J., and Muscheler, R.: Large variations in Holocene solar activity: Constraints from ${ }^{10} \mathrm{Be}$ in the Greenland Ice Core Project ice core, J. Geophys. Res., 111, A10105, doi:10.1029/2005JA011500, 2006.

Yiou, F., Raisbeck, G. M., Bourles, D., Lorius, C., and Barkov, N. I.: ${ }^{10} \mathrm{Be}$ in ice at Vostok Antarctica during the last climatic cycle, Nature, 316, 616-617, 1985. 